\title{
Identification of Klebsiella pneumoniae by DNA Hybridization and Fatty Acid Analysis
}

\author{
GONNIE SPIERINGS, ${ }^{1 *}$ ALBERT VAN SILFHOUT, ${ }^{2}$ HARM HOFSTRA,${ }^{3}$ AND JAN TOMMASSEN ${ }^{1}$ \\ Department of Molecular Cell Biology and Institute of Molecular Biology and Medical Biotechnology, University of \\ Utrecht, Padualaan 8, $3584 \mathrm{CH}$ Utrecht ${ }^{1}{ }^{1}$ Department of Bacteriology, National Institute for Public Health and \\ Environmental Protection, Bilthoven, ${ }^{2}$ and Department of Microbiology, Division for Nutrition and
} Food Research TNO, Zeist, ${ }^{3}$ The Netherlands

\begin{abstract}
On the basis of the idea that DNA sequences encoding cell surface-exposed regions of outer membrane proteins are genus or species specific, two oligonucleotide probes which were based on the PhoE protein of Klebsiella pneumoniae were evaluated. In slot blot hybridizations and in polymerase chain reactions, no cross-hybridizations were observed with non-Klebsiella strains. When the probes were tested on 75 different K-antigen reference Klebsiella strains, 16 strains were not recognized although they did produce PhoE protein under phosphate starvation. To determine whether these 16 strains belong to (a) different species, the reference strains were also tested for the ability to produce indole and to grow at $10^{\circ} \mathrm{C}$ and their whole-cell fatty acid patterns were analyzed by gas chromatography. A strong correlation was observed among (i) reaction with the probes, (ii) the inability to produce indole, (iii) the inability to grow at $10^{\circ} \mathrm{C}$, and (iv) the presence of the hydroxylated fatty acid $\mathrm{C}_{14: 0-2 \mathrm{OH}}$. From these results we conclude that the two oligonucleotides are specific for the species $K$. pneumoniae. Furthermore, analysis of fatty acid patterns appears to be a useful tool to distinguish $K$. pneumoniae from other Klebsiella species.
\end{abstract}

The genus Klebsiella consists of four species, i.e., $K$. pneumoniae (with subspecies pneumoniae, ozaenae, and rhinoscleromatis), $K$. oxytoca, $K$. planticola, and $K$. terrigena (12). Although the present definition of the genus is confined to nonmotile strains, proposals have been made to transfer Enterobacter aerogenes to the genus as $K$. mobilis $(2,5)$. The current classification of Klebsiella strains into the different species is based on their biochemical properties. The results of these assays are in many cases difficult to interpret. For instance, there is no key discriminatory test to differentiate the indole-negative $K$. planticola strains from $K$. pneumoniae (1). A genetically based procedure like the polymerase chain reaction (PCR) could potentially increase the precision and the rapidity and decrease the labor intensiveness of the identification.

The first step in the development of such an identification system is the selection of species-specific oligonucleotide probes. Recently, we have shown that DNA sequences encoding surface-exposed regions of outer membrane proteins can be used as specific probes (16). The phoE gene of members of the family Enterobacteriaceae encodes a poreforming outer membrane protein which is induced when the bacteria are grown under phosphate limitation (14). According to the proposed topology model, the polypeptide traverses the outer membrane 16 times in an antiparallel $\beta$-sheet structure, thereby exposing eight areas at the cell surface $(17,22)$. Comparison of the primary structures of different PhoE proteins revealed four hypervariable regions, all of which were predicted to be cell surface exposed, whereas the membrane-spanning regions were found to be highly conserved (21).

In this study, we have evaluated the potential of two oligonucleotide probes, based on the phoE gene of $K$. pneumoniae, to discriminate between different Klebsiella species. The sensitivity of the probes was tested on the $\mathrm{K}$ antigen reference strains described by $\emptyset$ rskov and $\emptyset$ rskov

\footnotetext{
* Corresponding author.
}

(13). The capsular polysaccharide, or $\mathrm{K}$ antigen, is most commonly used for serological typing of Klebsiella strains. The (lack of) reaction of the probes was correlated to species classification by testing the ability of the strains to produce indole and testing their growth at $10^{\circ} \mathrm{C}$. K. pneumoniae strains are negative in the indole test and are the only Klebsiella strains unable to grow at $10^{\circ} \mathrm{C}(12)$. As an independent method, the fatty acid content of the strains was analyzed by gas-liquid chromatography, which is also considered a powerful approach to differentiate between bacterial species (6).

\section{MATERIALS AND METHODS}

Bacterial strains and growth conditions. Escherichia coli K-12 strain CE1194, which carries a chromosomal phoE deletion, and its phoE ${ }^{+}$derivative CE1195 (19) and strain K10 (CGSC4234) (18) have been described elsewhere. Other enterobacterial strains used were Citrobacter freundii, Edwardsiella tarda, Enterobacter aerogenes, Enterobacter cloacae, K. pneumoniae, Providencia stuartii, Proteus mirabilis, Salmonella braenderup, Salmonella derby, Salmonella panama, Serratia marcescens, Shigella flexneri, and Shigella boydii, all described by Hofstra and Dankert (4), and Salmonella typhimurium SJ2353, described by Sato and Yura (15). Of the 77 different $\mathrm{K}$ antigen reference strains described by $\emptyset$ rskov and $\emptyset$ rskov (13), 75 (missing K6 and K49) were kindly provided by W. Jansen at the National Institute for Public Health and Environmental Protection in Bilthoven, The Netherlands. The nonenterobacterial strains used, i.e., Aeromonas hydrophila, Bacillus cereus, Pseudomonas aeruginosa, Sarcina flava, and Staphylococcus aureus, were from our laboratory stocks.

Unless mentioned otherwise, strains were grown overnight at $37^{\circ} \mathrm{C}$ under aeration in $\mathrm{L}$ broth (20). When strains were grown at $10^{\circ} \mathrm{C}$, incubation was continued for $48 \mathrm{~h}$.

Isolation and characterization of cell envelopes. Strains were grown overnight at $37^{\circ} \mathrm{C}$ under aeration in a medium (7) in which the phosphate concentration is limiting for growth. 

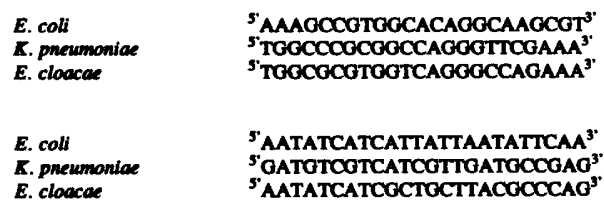

KPS s' TGOCGOGTOGTCAGGGCCAGAAA

5. AATATCATCATTATTAATATTCAA ${ }^{3}$. "SATOTOGTCATCGTTOATGCCGAG

KP8c

FIG. 1. Comparison of the DNA sequences of the Klebsiella probes with the corresponding sequences of the $p h o E$ genes of $E$. coli and E. cloacae. KP5 is based on the DNA complementary to the sequence encoding the fifth surface-exposed region of the phoE gene, and KP8c is based on the DNA sequence encoding the eighth surface-exposed region of the phoE gene of $K$. pneumoniae.

Phosphate-replete conditions were obtained by supplementing the medium with $660 \mu \mathrm{M} \mathrm{K}_{2} \mathrm{HPO}_{4}$. Cell envelopes were isolated by differential centrifugation after ultrasonic disintegration of the cells (8). The protein patterns were analyzed by sodium dodecyl sulfate (SDS)-polyacrylamide gel electrophoresis (8) using gels containing $6 \mathrm{M}$ urea.

Indole reaction. Indole tests were performed as described by Frobisher (3).

Synthesis and labeling of the oligonucleotides. Oligonucleotides were automatically synthesized on a Biosearch 8600 DNA synthesizer. When used in hybridization assays, the oligomers were labeled by the enzymatically catalyzed transfer of ${ }^{32} \mathrm{P}$ from $\left[\gamma^{32} \mathrm{P}\right]$ ATP $(3,000 \mathrm{Ci} / \mathrm{mmol}$; Amersham International) with $\mathrm{T} 4$ polynucleotide kinase (Pharmacia, Uppsala, Sweden) according to the procedure described by Maniatis et al. (9).

DNA hybridizations and PCR assays. Slot blot hybridization assays were performed as described previously (16), except that the incubation temperature during (pre)hybridization and washings was $63^{\circ} \mathrm{C}$ instead of $60^{\circ} \mathrm{C}$. DNA samples to be used in PCRs were isolated from 1-ml overnight cell cultures. Cells were harvested by centrifugation, resuspended in $100 \mu \mathrm{l}$ of demineralized water, and boiled for 5 min. Cell debris was removed by a 2 -min centrifugation step at $14,000 \times g$. PCR amplifications were performed on $5-\mu l$ samples of the supernatant fraction by using a DNA thermal cycler (PHC-1; New Brunswick plc. Int.). One unit of Taq polymerase (Promega, Madison, Wis.) was used as described by the manufacturer except that RNase (Boehringer, Mannheim, Germany) was added to a final concentration of $20 \mu \mathrm{g} / \mathrm{ml}$ and the total volume was adjusted to $25 \mu \mathrm{l}$. A total of 25 PCR cycles was run under the following conditions: denaturation at $94^{\circ} \mathrm{C}$ for $1 \mathrm{~min}$, primer annealing at $45^{\circ} \mathrm{C}$ for $2 \mathrm{~min}$, and DNA extension at $72^{\circ} \mathrm{C}$ for $2 \mathrm{~min}$ but for $5 \mathrm{~min}$ in the last cycle. Of the PCR products, $10-\mu$ l samples were analyzed by electrophoresis on $1 \%$ agarose gels.

Gas-liquid chromatographic analysis of fatty acids. For analysis of fatty acid patterns bacteria were harvested after growth for $24 \mathrm{~h}$ at $37^{\circ} \mathrm{C}$ on Trypticase soy broth (BBL Microbiology Systems, Cockeysville, Md.) solidified with $1.5 \%$ agar. Whole-cell fatty acids were analyzed as fatty acid methyl esters. Fatty acid methyl ester extracts were made by the techniques described by Miller and Berger (10). They were analyzed by high performance capillary gas-liquid chromatography with the MIDI Microbial Identification System (Microbial ID, Inc. Newark, Del.). The system configuration contained a Hewlett-Packard HP 5890 A gas chromatograph with autosampler and was equipped with a $25-\mathrm{m}$ Ultra 2 column and a flame ionization detector. The system was completed with a HP9000 series 300 computer system for analysis control, data acquisition, and data evaluation, using the MIDI library-generating software.

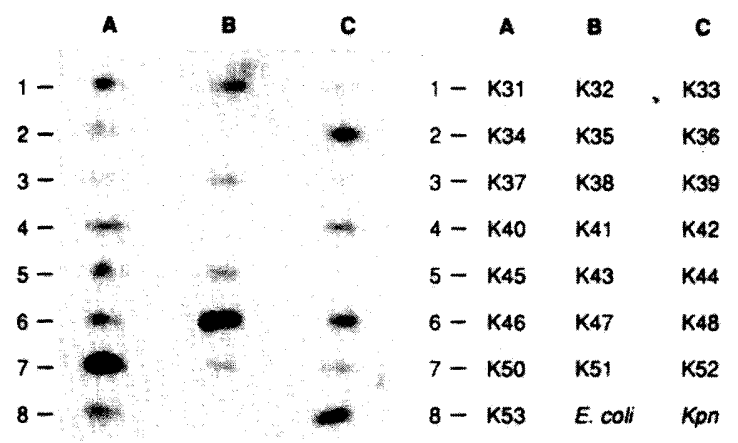

FIG. 2. Autoradiogram of a slot blot hybridization using probe KP5. The $\mathrm{K}$ strains are different Klebsiella $\mathrm{K}$ antigen reference strains. The E. coli strain used was CE1195. Kpn is an unserotyped $K$. pneumoniae strain, the $p h o E$ gene of which has been sequenced previously (21). The probes were based on this sequence.

\section{RESULTS}

The phoE gene of $K$. pneumoniae has been cloned and sequenced previously (21). Comparison of the DNA sequences of the phoE genes of $K$. pneumoniae, E. cloacae, and $E$. coli revealed four hypervariable regions, corresponding to cell surface-exposed segments of the PhoE proteins (21). The hypervariable regions where the homology between the proteins was the lowest were chosen for two oligonucleotide probes. Probes KP5 and KP8c were based on DNA sequences encoding the fifth and the eighth surfaceexposed regions of PhoE, respectively (Fig. 1). They correspond to segments of the noncoding and coding DNA strands, respectively, so that they can be used in PCRs. An ideal DNA probe has to be both sensitive and selective; i.e., it has to recognize all strains and serotypes of a certain taxon, but it should not cross-react with other bacteria. These conditions were tested in hybridization and PCR assays.

Sensitivity assays. The capacity of the probes to recognize different Klebsiella strains was tested on 75 of the 77 $\mathrm{K}$-antigen reference strains (13). The strains are named K1 to $\mathrm{K} 82 ; \mathrm{K} 73$ and $\mathrm{K} 75$ to $\mathrm{K} 78$ have been eliminated because of misdiagnosis and overlapping (13). Strains K6 and K49 were lost from our collection. The probes were tested on these strains in slot blot hybridization assays. An example of an autoradiogram is shown in Fig. 2. Both probes reacted

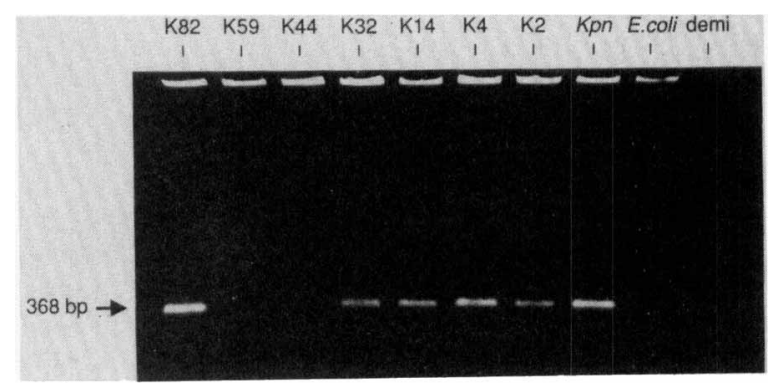

FIG. 3. Analysis of PCR products on a $1 \%$ agarose gel. The $\mathbf{K}$ strains are different Klebsiella $\mathbf{K}$ antigen reference strains. The $E$. coli strain used was CE1195. Kpn is an unserotyped $K$. pneumoniae strain, the phoE gene of which has been sequenced previously (21). The probes were based on this sequence. demi means that demineralized water was used as the substrate. 
TABLE 1. Characteristics of the Klebsiella strains

\begin{tabular}{|c|c|c|c|c|}
\hline Strain & $\begin{array}{c}\text { PCR } \\
\text { results }\end{array}$ & $\begin{array}{l}\text { Growth at } \\
10^{\circ} \mathrm{C}^{a}\end{array}$ & $\begin{array}{c}\text { Indole } \\
\text { production }\end{array}$ & $\begin{array}{l}\text { Presence of fatty } \\
\text { acid } C_{14: 0-2 O H}\end{array}$ \\
\hline K. pneumoniae ${ }^{b}$ & + & - & - & + \\
\hline $\mathrm{K} 1$ & + & - & - & + \\
\hline $\mathrm{K} 2$ & + & - & - & + \\
\hline $\mathrm{K} 3$ & + & - & - & + \\
\hline K4 & + & \pm & - & + \\
\hline K5 & - & - & - & + \\
\hline K7 & + & - & - & + \\
\hline K8 & + & \pm & - & + \\
\hline K9 & + & - & - & + \\
\hline K10 & + & \pm & - & + \\
\hline K11 & + & - & - & + \\
\hline $\mathrm{K} 12$ & + & \pm & - & + \\
\hline K13 & + & \pm & - & + \\
\hline K14 & + & \pm & - & + \\
\hline K15 & + & - & - & + \\
\hline K16 & + & - & - & + \\
\hline K17 & + & - & - & + \\
\hline K18 & + & - & - & + \\
\hline K19 & + & \pm & - & + \\
\hline $\mathrm{K} 20$ & + & - & - & + \\
\hline K21 & + & - & - & + \\
\hline $\mathrm{K} 22$ & + & \pm & - & + \\
\hline K23 & + & - & - & + \\
\hline $\mathrm{K} 24$ & + & \pm & - & + \\
\hline $\mathrm{K} 25$ & + & - & - & + \\
\hline $\mathrm{K} 26$ & - & ++ & + & - \\
\hline K27 & + & \pm & - & + \\
\hline K28 & + & - & - & + \\
\hline K29 & - & ++ & + & - \\
\hline K30 & + & \pm & - & + \\
\hline K31 & + & \pm & - & + \\
\hline K32 & + & \pm & - & + \\
\hline $\mathrm{K} 33$ & + & - & - & + \\
\hline K34 & + & \pm & - & + \\
\hline K35 & - & ++ & - & - \\
\hline $\mathrm{K} 36$ & + & \pm & - & + \\
\hline K37 & + & - & - & + \\
\hline K38 & + & - & _- & + \\
\hline K39 & + & - & - & + \\
\hline K40 & + & - & - & + \\
\hline K41 & - & ++ & + & - \\
\hline $\mathrm{K} 42$ & + & \pm & - & + \\
\hline K43 & + & \pm & - & + \\
\hline K44 & - & ++ & + & - \\
\hline K45 & + & \pm & - & + \\
\hline $\mathrm{K} 46$ & + & \pm & - & + \\
\hline K47 & + & \pm & - & + \\
\hline K48 & + & \pm & - & + \\
\hline $\mathrm{K} 50$ & + & - & - & + \\
\hline K51 & + & - & - & + \\
\hline K52 & + & - & - & + \\
\hline $\mathrm{K} 53$ & + & \pm & - & + \\
\hline K54 & + & \pm & - & + \\
\hline K55 & + & \pm & - & + \\
\hline K56 & + & \pm & - & + \\
\hline $\mathrm{K} 57$ & + & $\overline{-}$ & - & + \\
\hline K58 & + & \pm & - & + \\
\hline K59 & - & ++ & - & - \\
\hline K60 & + & - & - & + \\
\hline K61 & + & - & - & + \\
\hline K62 & + & - & - & + \\
\hline K63 & + & - & - & + \\
\hline K64 & + & - & - & + \\
\hline K65 & - & ++ & - & - \\
\hline K66 & - & ++ & + & - \\
\hline K67 & - & ++ & - & - \\
\hline K68 & - & ++ & - & - \\
\hline
\end{tabular}

Continued
TABLE 1-Continued

\begin{tabular}{|c|c|c|c|c|}
\hline Strain & $\begin{array}{l}\text { PCR } \\
\text { results }\end{array}$ & $\begin{array}{l}\text { Growth at } \\
10^{\circ} \mathrm{C}^{a}\end{array}$ & $\begin{array}{l}\text { Indole } \\
\text { production }\end{array}$ & $\begin{array}{l}\text { Presence of fatty } \\
\text { acid } C_{14:(0-2 O H}\end{array}$ \\
\hline K69 & - & ++ & - & - \\
\hline K70 & - & \pm & + & - \\
\hline K71 & + & - & - & + \\
\hline K72 & - & ++ & + & - \\
\hline K74 & - & ++ & + & - \\
\hline K79 & - & ++ & - & - \\
\hline K80 & + & \pm & - & + \\
\hline K81 & + & - & - & + \\
\hline K82 & + & \pm & - & + \\
\hline
\end{tabular}

${ }^{a}$ Symbols for optical density (OD) values at $\lambda=660 \mathrm{~nm}$ after $48 \mathrm{~h}:-$, OD $<0.1 ; \pm, 0.1 \leq \mathrm{OD}<0.5 ;++, \mathrm{OD} \geq 1$.

${ }^{b} K$. pneumoniae is an unserotyped strain, the phoE gene of which has been sequenced previously (19). The probes were based on this sequence.

with 59 of the 75 strains, and each of them failed to recognize 16 strains, which were the same strains in both cases. The probes were designed in such a way that they could also be used as primers in PCRs. When the primers recognize their complementary sequences, there will be amplified a 368-bp DNA fragment which can be detected when the PCR products are analyzed by electrophoresis on agarose gels. An example of such an analysis is shown in Fig. 3. The expected amplified fragment was observed in the same 59 strains that reacted positively in the slot blot hybridization assays, whereas the remaining strains again were negative (Table 1).

Selectivity assays. To test the selectivity of the probes, the 14 different non-Klebsiella strains belonging to the Enterobacteriaceae and 5 non-Enterobacteriaceae strains mentioned in Material and Methods were tested in slot blot hybridizations. The results of probe KP8c have been published earlier (16) and showed that only the $K$. pneumoniae strain from which the phoE nucleotide sequence was established was recognized. Similar results were found when KP5 was used as the probe or when KP5 and KP8c were used together in PCRs (data not shown).

Expression of the phoE genes. The two probes turned out to be selective, since they did not recognize any other strains except Klebsiella strains, but when tested for their sensitivity, they failed to recognize 16 of 75 Klebsiella strains, i.e., K5, K26, K29, K35, K41, K44, K59, K65 to K70, K72, K74, and $\mathrm{K} 79$. To test whether these strains contain a phoE gene, a number of them were grown under high- and low-phosphate conditions and their cell envelope protein patterns were analyzed. Figure 4 shows that all tested Klebsiella strains induced a membrane protein of the expected apparent molecular weight when grown under low-phosphate conditions. Of the strains tested, K26, K29, K44, K59, and K65 did not react with the probes. The DNA sequence of their $p h o E$ genes must therefore differ from those of strains recognized by the probes.

Species classification reactions. To determine whether the different reactions with the DNA probes can be correlated to differences at the species level, more information about the 75 Klebsiella strains was necessary. Therefore, the strains were tested for the ability to produce indole and to grow at $10^{\circ} \mathrm{C}$ (Table 1). Strains that are positive in the indole test belong to either the species $K$. oxytoca or $K$. planticola, and of the different Klebsiella species, only $K$. pneumoniae is not able to grow at $10^{\circ} \mathrm{C}(12)$. All strains found to produce indole, i.e., K26, K29, K41, K44, K66, K70, K72, and K74, were not recognized by the probes. Furthermore, we found a 


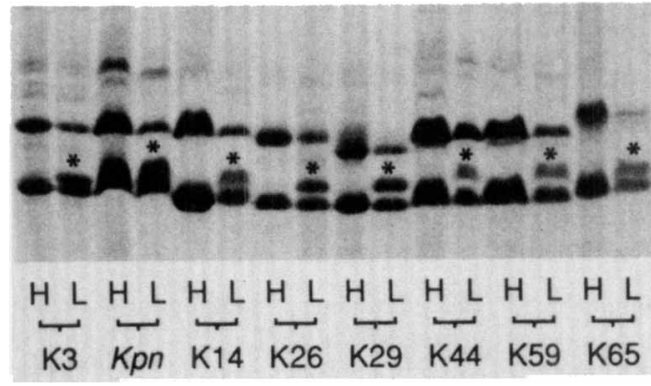

FIG. 4. SDS-polyacrylamide gel electrophoresis patterns of cell envelope proteins of Klebsiella strains either grown under highphosphate $(\mathrm{H})$ or low-phosphate $(\mathrm{L})$ conditions. The PhoE proteins are indicated with asterisks. Only the relevant part of the gel is shown.

strong correlation between positive results in the probe assays and no or poor growth at $10^{\circ} \mathrm{C}$ (Table 1 ). The strains that gave negative results in the probe assays, on the other hand, could all grow at $10^{\circ} \mathrm{C}$, except for strains $\mathrm{K} 5$ and $\mathrm{K} 70$, which showed no and poor growth, respectively.

Gas-liquid chromatographic analysis of fatty acids. The analysis of fatty acid content has been propagated for the identification of bacterial species (6) but has, to our knowledge, never been used to differentiate between different Klebsiella species. Therefore, as a totally independent determination method, the fatty acid methyl esters of the isolated phospholipids of the 75 Klebsiella strains were analyzed. The most common fatty acids found in all the Klebsiella strains were $\mathrm{C}_{16: 0}(34 \%), \mathrm{C}_{17: 0 \text { cyclo }}(14 \%)$, and $\mathrm{C}_{14: 0}(9 \%)$. The major hydroxylated fatty acid found was $\mathrm{C}_{14: 0-2 \mathrm{OH}}(2 \%)$. Interestingly, only those Klebsiella strains that were recognized by the probes contained this hydroxylated fatty acid, whereas the strains which were not recognized by the probes did not (Table 1 ). The only exception is strain $\mathrm{K5}$, which, although negative in the probe assays, contains fatty acid $\mathrm{C}_{14: 0-2 \mathrm{OH}}$. Strain $\mathrm{K} 60$, which is positive in the probe assays, does contain fatty acid $\mathrm{C}_{14: 0-2 \mathrm{OH}}$, albeit at a lower level (1\%).

\section{DISCUSSION}

The two Klebsiella probes evaluated in this study were found to be selective; i.e., no cross-reactivity occurred with tested Enterobacteriaceae strains other than Klebsiella strains and with non-Enterobacteriaceae strains. When the probes were tested on 75 of the $77 \mathrm{~K}$ antigen reference strains, 16 strains were not recognized. Among these strains are $\mathrm{K} 26, \mathrm{~K} 29, \mathrm{~K} 44, \mathrm{~K} 59$, and $\mathrm{K} 65$, which normally induced a PhoE protein when grown under phosphate limitation (Fig. 4). Therefore, the phoE gene is probably commonly present in Klebsiella strains. An explanation for the fact that 16 of the Klebsiella strains were not recognized by the probes might be that the probes are specific for the species $K$. pneumoniae. It has been known for some time that a number of the $\mathrm{K}$ antigen reference strains are $K$. oxytoca strains (12), and more recent research has indicated that $K$. planticola and $K$. terrigena strains might also be present in this collection (11). To obtain more information on the species classification of the Klebsiella strains, their ability to produce indole and to grow at $10^{\circ} \mathrm{C}$ and their whole-cell fatty acid patterns were analyzed. A good correlation was observed among (i) reaction with the probes, (ii) the inability to produce indole, (iii) the inability to grow at $10^{\circ} \mathrm{C}$, and (iv) the presence of the hydroxylated fatty acid $\mathrm{C}_{14: 0-2 \mathrm{OH}}$. Only two exceptions were found. Strain $\mathrm{K} 5$, despite its inability to grow at $10^{\circ} \mathrm{C}$ and the presence of $\mathrm{C}_{14: 0-2 \mathrm{OH}}$ in its fatty acid profile, was not recognized by the probes. This strain, like $\mathrm{K} 4$, which normally reacted with the probes, has been classified as a $K$. ozaenae strain (12a). Strain K70, although positive in the indole test, negative in the probe assays, and missing fatty acid $\mathrm{C}_{14: 0-20 \mathrm{H}}$, showed only poor growth at $10^{\circ} \mathrm{C}$.

From the results, we conclude that recognition by the probes is probably restricted to the species $K$. pneumoniae and that therefore, with the exception of strain $\mathrm{K} 5$, all strains which are not recognized by the probes belong to other Klebsiella species. The finding that K26, K29, K35, K41, K44, K59, K65, K66, K70, K72, K74, and K79 do not belong to the species $K$. pneumoniae is in agreement with the results of Mori et al. (11). However strains K67, K68, and $\mathrm{K} 69$, which, according to our tests, did not behave like $K$. pneumoniae strains, were classified as such by Mori et al. On the other hand, strains K8, K14, K32, K39, K48, K49, $\mathrm{K} 56, \mathrm{~K} 57, \mathrm{~K} 58$, and $\mathrm{K} 71$, classified by Mori et al. as $K$. planticola strains, behaved in our tests as normal $K$. pneumoniae strains. Most differences occur in differentiating $K$. pneumoniae strains from the indole-negative $K$. planticola strains. Since there is no key discriminatory test in the biochemical classification, Mori et al. used, as recommended by Bagley et al. (1), a combination of an L-sorbose fermentation test and a hydroxy-L-proline utilization test to distinguish between the two species. Also, two other tests, namely, the fecal coliform reaction at $44.5^{\circ} \mathrm{C}$ and growth at $10^{\circ} \mathrm{C}$, were used. Mori et al. found only $65 \%$ of the strains which were fecal coliform negative and had growth at $10^{\circ} \mathrm{C}$ to be positive in the tests recommended by Bagley et al., whereas Bagley et al. found a correlation of more then $90 \%$. According to Ørskov, some Klebsiella strains are biochemically hard to classify (12a).

The above-mentioned results demonstrate the difficulty in the biochemical classification assays to distinguish $K$. pneumoniae from indole-negative $K$. planticola. In our opinion, the use of the DNA probes as described in this article and the analysis of fatty acid content will contribute to a more precise classification of Klebsiella strains. Moreover, the use of these probes will lead to more rapid detection and classification assays. Presently, we are developing similar DNA probes for the other Klebsiella species to enable the specific detection and identification of these species as well.

\section{ACKNOWLEDGMENTS}

We thank W. Jansen for providing Klebsiella strains and M. Heck and $H$. Daalderop for technical assistance. We thank I. Ørskov for communicating unpublished results.

This work was supported by Holland Biotechnology (H.B.T.) and by the Netherlands Technology Foundation (S.T.W.).

\section{REFERENCES}

1. Bagley, S. T., R. J. Seidler, and D. J. Brenner. 1981. Klebsiella planticola sp. nov.: a new species of Enterobacteriaceae found primarily in nonclinical environments. Curr. Microbiol. 6:105109.

2. Bascomb, S., S. P. Lapage, W. R. Willcox, and M. A. Curtis. 1971. Numerical classification of the tribe Klebsielleae. J. Gen. Microbiol. 66:279-295.

3. Frobisher, M. 1957. Fundamentals of microbiology, 6th ed., p. 242. The W. B. Saunders Co., Philadelphia.

4. Hofstra, H., and J. Dankert. 1980. Major outer membrane proteins: common antigens in Enterobacteriaceae species. J. Gen. Microbiol. 119:123-131. 
5. Izard, D., F. Gavini, and H. Leclerc. 1980. Polynucleotide sequence relatedness and genome size among Enterobacter intermedium sp. nov. and the species Enterobacter cloacae and Klebsiella pneumoniae. Zentralbl. Bakteriol Abt. 1 Orig. C 1:51-60.

6. Lechevalier, M. P. 1977 . Lipids in bacterial taxonomy-a taxonomist's view. Crit. Rev. Microbiol. 5:109-210.

7. Levinthal, C., E. R. Signer, and K. Fetherolf. 1962. Reaction and hybridization of reduced alkaline phosphatase. Proc. Natl. Acad. Sci. USA 48:1230-1237.

8. Lugtenberg, B., J. Meijers, R. Peters, P. van der Hoek, and L. van Alphen. 1975. Electrophoretic resolution of the "major outer membrane protein" of Escherichia coli K-12 into four bands. FEBS Lett. 58:254-258.

9. Maniatis, T., E. F. Fritsch, and J. Sambrook. 1982. Molecular cloning: a laboratory manual. Cold Spring Harbor Laboratory, Cold Spring Harbor, N.Y.

10. Miller, I., and T. Berger. 1985. Hewlett-Packard application note, p. 228-241. Hewlett-Packard Co., Palo Alto, Calif.

11. Mori, M., M. Ohta, N. Agata, N. Kido, Y. Arakawa, H. Ito, T. Komatsu, and N. Kato. 1989. Identification of species and capsular types of Klebsiella clinical isolates, with special reference to Klebsiella planticola. Microbiol. Immunol. 33:887-895.

12. Ørskov, I. 1984. Genus V. Klebsiella Trevisan $1885,105^{\mathrm{AL}}$, p. 461-465. In N. R. Krieg and J. G. Holt (ed.), Bergey's manual of systematic bacteriology, vol. 1. The Williams \& Wilkins Co., Baltimore.

12a.Ørskov, I. Personal communication.

13. Ørskov, I., and F. Ørskov. 1984. Serotyping of Klebsiella. Methods Microbiol. 14:143-164.

14. Overbeeke, N., and B. Lugtenberg. 1980. Expression of outer membrane protein e of Escherichia coli $\mathrm{K}-12$ by phosphate limitation. FEBS Lett. 112:229-232.
15. Sato, T., and T. Yura. 1979. Chromosomal localization and expression of the structural gene for major outer membrane protein 1a of Escherichia coli $\mathrm{K}-12$ and of the homologous gene of Salmonella typhimurium. J. Bacteriol. 139:468-477.

16. Spierings, G., H. Hofstra, J. Huis in't Veld, W. Hoekstra, and J. Tommassen. 1989. Development of enterobacterium-specific oligonucleotide probes based on the surface-exposed regions of outer membrane proteins. Appl. Environ. Microbiol. 55:3250 3252 .

17. Tommassen, J. 1988. Biogenesis and topology of outer membrane proteins in Escherichia coli, p. 351-373. In J. A. F. Op den Kamp (ed.), Membrane biogenesis. NATO ASI series, vol. H16. Springer-Verlag KG, Berlin.

18. Tommassen, J., and B. Lugtenberg. 1980. Outer membrane protein e of Escherichia coli $\mathrm{K}-12$ is co-regulated with alkaline phosphatase. J. Bacteriol. 143:151-157.

19. Tommassen, J., P. Overduin, B. Lugtenberg, and H. Bergmans. 1982. Cloning of phoE, the structural gene for the Escherichia coli phosphate limitation-inducible outer membrane pore protein. J. Bacteriol. 149:668-672.

20. Tommassen, J., H. van Tol, and B. Lugtenberg. 1983. The ultimate localization of an outer membrane protein of Escherichia coli $\mathrm{K}-12$ is not determined by the signal sequence. EMBO J. 2:1275-1279.

21. Van der Ley, P., A. Bekkers, J. van Meersbergen, and J. Tommassen. 1987. A comparative study on the phoE genes of three enterobacterial species. Implications for structure-function relationships in a pore-forming protein of the outer membrane. Eur. J. Biochem. 164:469-475.

22. Van der Ley, P., M. Struyvé, and J. Tommassen. 1986. Topology of outer membrane pore protein phoE of Escherichia coli. J. Biol. Chem. 261:12222-12225. 